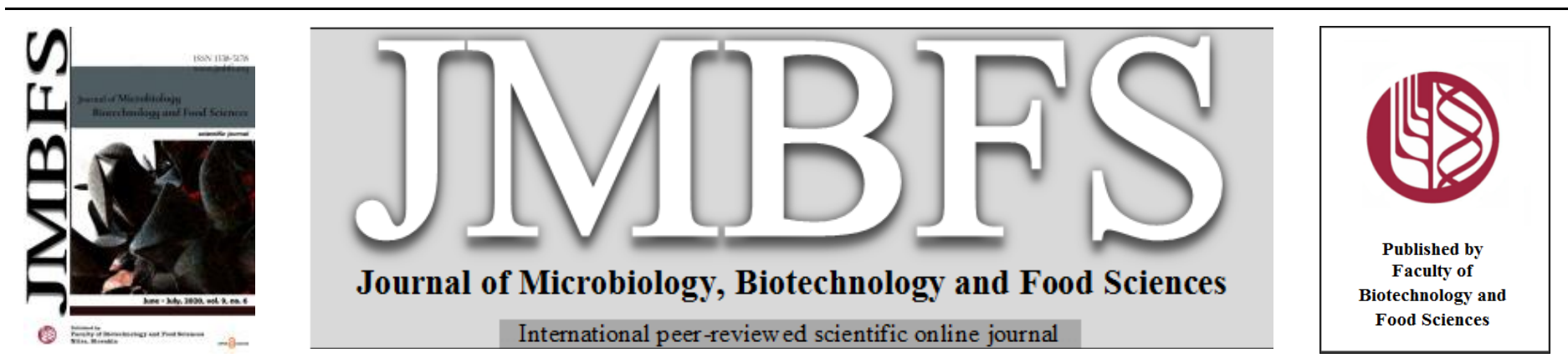

\title{
SCREENING OF ANTI-CLOSTRIDIAL LACTIC ACID BACTERIA STRAINS ISOLATED FROM URUGUAYAN DAIRY FARMS
}

\author{
Jorge Olivera Rodi ${ }^{*}$, Marcela Joan González Ramos ${ }^{1}$, Pedro Díaz Gadea ${ }^{2}$, and Stella Maris Reginensi ${ }^{1}$ \\ Address(es): M.Sc. Jorge Olivera, \\ ${ }^{1}$ Unidad de Tecnología de los Alimentos, Facultad de Agronomía, Garzón 780, CP 12900, Montevideo, Uruguay, + 59823547991. \\ ${ }^{2}$ Laboratorio de Bioquímica, Departamento de Biología Vegetal, Facultad de Agronomía, Garzón 780, CP 12900, Montevideo, Uruguay, + 59823553939.
}

*Corresponding author: jolivera3@gmail.com

doi: 10.15414/jmbfs.2020.9.6.1170-1175

\section{ARTICLE INFO}

Received 17. 7. 2019

Revised 13. 2. 2020

Accepted 17. 2. 2020

Published 1. 6. 2020

Regular article OPEN $\partial_{\text {ACCESS }}$

\begin{abstract}
A total of 130 strains of lactic acid bacteria (starter lactic acid bacteria -SLAB- and non-starter lactic acid bacteria -NSLAB-) were isolated from milk, whey and cheese. Anti-clostridial activity was detected in 56 isolates against Clostridium tyrobutyricum ATCC 25755. Seven strains with the highest inhibitory activity were selected to determine their inhibitory mechanisms. Anti-clostridial activity of strains Streptococcus macedonicus 23, S. macedonicus 24, Lactobacillus casei/paracasei 29 and Lactobacillus rhamnosus 104 was due to organic acids production. Inhibitory mechanisms of strains L. casei 26 and 95 were acid production, bacteriocin and hydrogen peroxide. While anti-clostridial activity of Lactobacillus delbrueckii subsp. bulgaricus 76 was due to acid and hydrogen peroxide production. Cell-free supernatants obtained from strains 26, 95 and 76 conserved their anti-clostridial activity after thermal treatments at 70 and $100{ }^{\circ} \mathrm{C}$. Supernatants obtained from bacteriogenic strains 26 and 95 were analyzed by RP-HPLC. RP-HPLC fractions with anticlostridial activity were analyzed by mass spectrometry (MALDI-TOF). A peptide with molecular weight of 1162.54 Da was detected in HPLC fraction of $L$. casei 95 . No results were obtained for MALDI-TOF analysis of another HPLC fractions. Based on the thermostability and low molecular weight, $L$. casei 95 anti-clostridial peptide would belong to a class I or II bacteriocin according to Gram-positive bacteria antimicrobial peptides classification.
\end{abstract}

Keywords: LAB, NSLAB, SLAB, Clostridium, bacteriocin, inhibition, late blowing

\section{INTRODUCTION}

Late blowing defect is one of the major causes of spoilage in semi-hard and hard ripened cheeses. Lactate-fermenting clostridia cause this defect, characterized by excessive gas production and off-flavors. Clostridial spores are able to survive the milk pasteurization and cheese-making processes, remaining in the cheese during ripening. Clostridium metabolism of lactate includes the production of organic acids (butyric and acetic), carbon dioxide and hydrogen, resulting in irregular eyes, splits and cracks in the cheese, as well as undesirable aroma and flavors (Alvenäs, 2015; Calamari et al., 2018). Clostridium tyrobutyricum is considered the primary cause of late blowing in cheese, other clostridial species such as Clostridium sporogenes, Clostridium beijerinckii and Clostridium butyricum also have been shown to significantly contribute to the appearance of this defect (Garde et al., 2013; Bermúdez et al., 2016).

Much work has been undertaken to reduce the number of spores in milk and to prevent spore germination and growth in cheese. Farm-management and good hygienic milking practices are essential to reduce raw milk clostridial contamination (Gupta and Brightwell, 2017; Komori et al., 2018). In the cheesemaking process many strategies have been proposed to prevent late blowing defect like addition of lysozyme and physical spores removal by bactofugation or microfiltration. However, the reduction in spore numbers achieved by bactofugation may be insufficient to prevent late blowing defect if spore load is very high. On the other hand, microfiltration can only be applied to skimmed milk. Regarding the use of lysozyme, there is an increasing demand from consumers for foods with low chemical additive content (Ávila et al., 2014; Garde et al., 2011; Brändle et al., 2016). As an alternative, addition of lactic acid bacteria (LAB) strains, biologically active against Clostridium, as starter (SLAB) or adjunct cultures (non-starter LAB -NSLAB-) in cheese manufacture has been proposed (Gómez, 2017).

$\mathrm{LAB}$ are considered as natural preservatives due to the production of antimicrobial metabolites such as organic acids (lactic and acetic), hydrogen peroxide, acetaldehyde, diacetyl, acetoin, fatty acids, carbon dioxide, ethanol, Damino acids, reutericyclin, reuterin and bacteriocins (Özogul and Hamed, 2018; García-Cano et al., 2019).
Bacteriocins are ribosomally synthesized peptides of 20 to 60 amino acids length, with antibacterial activity towards closely related microorganisms, although there are bacteriocins with a broad range of antimicrobial activity. The best known mechanism of action of these peptides is the pore formation in the cell membrane of bacteria. As consequence of the loss of essential ions and metabolites through the pores, as well as the dissipation of the proton-motive force, the biosynthesis processes stop which leads to cell death. Bacteriocins of subclass Ia, such as nisin, are able to inhibit clostridial spores outgrowth. They can also inhibit cell wall synthesis by binding to lipid II, responsible for peptidoglycan subunits transfer (Dickman et al., 2019; Kumariya et al., 2019). Research on broad spectrum $\mathrm{LAB}$ bacteriocins, tolerant to high thermal stress and $\mathrm{pH}<6.0$, has gained interest for their use in dairy products. A current strategy in some food industrial processes is the addition of bacteriocin produced ex situ or the incorporation of LAB strains for in situ bacteriocin production. Nisin is the only antimicrobial peptide approved as food preservative worldwide (Perez $\boldsymbol{e t}$ al., 2014; Martínez et al., 2016; Silva et al., 2018).

The application of bacteriocins for biopreservation of foods usually includes the following approaches: inoculation of food with the bacteriocin-producer strain; addition of purified or semi-purified bacteriocin as food additive; and use of a product previously fermented with a bacteriocin-producing strain as an ingredient in food processing (Silva et al., 2018).

The aim of this study was therefore to isolate anti-clostridial lactic acid bacteria (SLAB and NSLAB) present in dairy products from artisanal cheesemaking farmhouses and to determine the nature of its inhibitory activity against Clostridium spp..

\section{MATERIALS AND METHODS}

Isolation of anti-clostridial lactic acid bacteria

Thirty raw milk, whey and cheese samples were obtained from ten Uruguayan artisanal cheesemaking farmhouses. Farmers produce cheese with their own milk using non-commercial microbial starters. Decimal dilutions were plated on de 
Man, Rogosa and Sharpe agar (MRS, Oxoid Ltd., UK) and incubated at 30 and $42{ }^{\circ} \mathrm{C}$ for $48 \mathrm{~h}$ under microaerophilic and anaerobic conditions using an Anoxomat Mark II device (Advanced Instruments Inc., USA). Approximately five colonies were picked randomly from each plate and isolated for further analysis. Typical LAB isolates were selected according to colony description, cell morphology, Gram staining and routine biochemical test.

LAB isolates with inhibitory effect against $C$. tyrobutyricum ATCC 25755 were detected by two screening test. In a first screening, $130 \mathrm{LAB}$ isolates were analyzed in cross-streak inhibition assay according to Christiansen $\boldsymbol{e t}$ al. (2005) Anti-clostridial activity indicator strain C. tyrobutyricum ATCC 25755, and LAB isolations were inoculated in Reinforced Clostridium Medium (RCM, Difco, USA) and MRS broth respectively, incubated anaerobically at $37{ }^{\circ} \mathrm{C}$ for $24-48$ h. Indicator strain was streaked on RCM agar and LAB isolates were streaked across the lane of $C$. tyrobutyricum ATCC 25755. Plates were incubated anaerobically at $37^{\circ} \mathrm{C}$ for $48 \mathrm{~h}$. Anti-clostridial LAB strains were detected by the absence of $C$. tyrobutyricum ATCC 25755 growth around the streaks. A second screening test using disc diffusion assay was performed. LAB isolates showing anti-clostridial activity in the first screening test, were grown in $50 \mathrm{~mL}$ of MRS broth in a $100 \mathrm{~mL}$ Erlenmeyer flask and incubated at $37^{\circ} \mathrm{C}$ during 16 $18 \mathrm{~h}$. Supernatants were obtained by centrifugation at $10000 \mathrm{rpm}$ for $15 \mathrm{~min}$ at 4 ${ }^{\circ} \mathrm{C}$, and filtered with $0.22 \mu \mathrm{m}$ pore size filter (Millipore, MA, USA). A log-phase culture of $C$. tyrobutyricum ATCC 25755 in RCM broth was adjusted to optical density $0.2-0.3$ at $620 \mathrm{~nm}$ and $100 \mu \mathrm{L}$ were spread on RCM agar plates. For disc diffusion assay, $100 \mu \mathrm{L}$ of cell-free supernatants were inoculated onto filter paper discs (diameter $6 \mathrm{~mm}$, Whatman, GE Health Care, NJ, USA) placed on RCM plates. Plates were incubated anaerobically at $37^{\circ} \mathrm{C}$ for $48 \mathrm{~h}$ (Jones $\boldsymbol{e t .}$ al., 2008; Matamoros et al., 2009). Antimicrobial activity was evaluated comparing the diameter of the halo around the disc. Commercially available anti-clostridia strain L. casei BAL C (LC4P1, Sacco SRL, Cadorago, CO, Italy), was included in the assay. Inhibition results were statistical analyzed by One-way ANOVA. Differences were considered statistically significant at $\mathrm{p}<0.05$

\section{Identification of anti-clostridial LAB strains}

Anti-clostridial LAB isolates were identified by $16 \mathrm{~S}$ rRNA sequencing Preparation of genomic DNA was performed from bacterial overnight cultures in MRS broth, cells were harvested at $10000 \mathrm{rpm}$ for $5 \mathrm{~min}$., and DNA was purified using GeneJet Genomic DNA Purification kit (Thermo Fisher Scientific, Lithuania) following the manufacturer's instructions. Purified DNA was suspended in $100 \mu \mathrm{L}$ TE buffer and used as template in amplification reactions. DNA concentration was determined using a NanoDrop 2000 spectrophotometer (Termo Scientific Incorporation, Wilmington, DE, USA)

For amplification reactions of the 16S rRNA gene, primers rD1 (5'AAGGAGGTGATCCAGCC-3') and fD1 (5'-AGAGTTTGATCCTGGCTCAG3') were used according to the protocols of Weisburg et al., (1991). Amplicons were visualized by electrophoresis in $1 \%$ agarose gels. Amplified fragments were purified and sequenced by Macrogen Sequencing Service, Korea, in an ABI PRISM 3730XL capillary sequencer, using the primer fD1 already described. DNA sequences were compared by BLAST analysis with those existing in the NCBI BLAST database (http://blast.ncbi.nlm.nih.gov/Blast.cgi).

\section{Nature of anti-clostridial compounds and sensitivity to heat treatments}

Cell-free supernatants of seven LAB strains showing the highest anti-clostridia activity in disc diffusion assay were prepared as previously mentioned. $L$. casei BAL C was included in this study. Nature of anti-clostridial compounds present in the cell-free culture supernatants was elucidated by disc diffusion method. To reject the inhibitory action of organic acids, the cell-free supernatants were adjusted to $\mathrm{pH} 6.5$ using $\mathrm{NaOH} 1 \mathrm{M}$ and concentrated $10 \mathrm{X}$ by rotary vacuum evaporation at $270 \mathrm{rpm}$ and $70{ }^{\circ} \mathrm{C}$. Neutralized supernatants were treated with proteinase $\mathrm{K}(2.5 \mathrm{mg} / \mathrm{mL}$, Sigma Aldrich, MO, USA) to detect antimicrobial peptide compounds and with catalase $(1.0 \mathrm{mg} / \mathrm{mL}$, Sigma Aldrich, MO, USA) for hydrogen peroxide production at $37^{\circ} \mathrm{C}$ for $3 \mathrm{~h}$ (Mathot et al., 2003; Jones et. al., 2008). Supernatants without enzymatic treatment were included as positive control. Paper discs with $100 \mu \mathrm{L}$ of each treated cell-free supernatants on RCM agar plates were previously spread with C. tyrobutyricum ATCC 25755 Inhibition of growth around the discs was examined after incubation at $37^{\circ} \mathrm{C}$ for $48 \mathrm{~h}$ in anaerobic condition. Isolates that produce anti-clostridial compounds other than organic acids, were selected for further analysis

To test heat stability of anti-clostridial compounds, neutralized supernatants were heated at 70 and $100{ }^{\circ} \mathrm{C}$ for $15 \mathrm{~min}$ in a temperature-controlled water bath Remaining anti-clostridial activity was determined by disc diffusion method with C. tyrobutyricum ATCC 25755 as indicator microorganism, as described above (Mathot et al., 2003).

\section{Purification and characterization of anti-clostridial peptides}

Anti-clostridial peptides of $L$. casei BAL C and three bacteriocinogenic LAB isolates were characterized. Cell-free supernatants from $250 \mathrm{~mL}$ of MRS culture broth were adjusted to $\mathrm{pH} 6.5$ with $\mathrm{NaOH} 1 \mathrm{M}$. Ice-cold acetone was added to the extent of 50\% saturation under cold stirring for 15 min (Pal et al., 2010). Mix was kept at $-20{ }^{\circ} \mathrm{C}$ overnight and then acetone was discarded. Residual acetone was removed by evaporation at $37^{\circ} \mathrm{C}$. Protein precipitates were resuspended in distilled water and concentrated $10 \mathrm{X}$ by rotary vacuum evaporation at $70{ }^{\circ} \mathrm{C}$ under agitation at $240 \mathrm{rpm}$ in a Heidolph Laborota 4000 Rotatory Evaporator (Heidolph Instruments GmbH \& CO. KG, Schwabach, Germany). The resulting protein crude extracts were filtered with $0.22 \mu \mathrm{m}$ pore size filter and the anticlostridial activity was verified.

Anti-clostridial peptides purification was realized by analytical RP-HPLC (Shimadzu, LC-20A). All chromatographic processes were performed on a C18 column. The column was equilibrated with solution A $(95 \%$ ultrapure water, $0.1 \%$ trifluoroacetic acid and 5\% acetonitrile) and solution B $(0.1 \%$ trifluoroacetic acid and $100 \%$ acetonitrile). Elution program was as follow: $100 \%$ solution A for $5 \mathrm{~min}$., solution A linearly decreased to $0 \%$ and solution B increased to $100 \%$, finally solution B was maintained at $100 \%$ for $30 \mathrm{~min}$. to 40 min. The flow rate was $1 \mathrm{~mL} / \mathrm{min}$ and elution was monitored by UV detector at $220 \mathrm{~nm}$ (Lü et $\boldsymbol{a l}$., 2014). HPLC eluted fractions were collected and their anticlostridial activity was evaluated against $C$. tyrobutyricum ATCC 25755 by disc diffusion assay.

MALDI-TOF mass spectrometry was used to determinate the molecular mass of peptides in HPLC eluted fractions. Mass spectra of digestion mixtures were acquired using a matrix assisted laser desorption/ionization time-of-flight mass spectrometer (MALDI-TOF/TOF, 4800Analyzer, ABiSciex) in positive reflector mode. Collision induced dissociation (CID) MS/MS spectra of selected peptides ions were also acquired. Proteins were identified with measured $\mathrm{m} / \mathrm{z}$ values in MS and MS/MS acquisition modes and using the MASCOT search engine (MatrixScience, http://www.matrixscience.com) in the Sequence Query search mode.

\section{RESULTS AND DISCUSSION}

\section{Screening and identification of anti-clostridial LAB strains}

A total of $130 \mathrm{LAB}$ were isolated from milk, cheese and whey samples. Isolates were evaluated for their ability to produce anti-clostridial compounds by crossstreak inhibition assay. Inhibitory activity against $C$. tyrobutyricum ATCC 25755 was observed in 56 isolates, 17 were isolated from milk, 29 from cheese and 10 from whey samples (data not shown).

Isolates with anti-clostridial activity were identified by $16 \mathrm{~S}$ rRNA gene sequencing. Most isolates belonged to the Lactobacillus casei Group $(66.1 \%)(L$. casei, L. paracasei and L. rhamnosus), followed by Lactobacillus delbruecki (7.1\%), Streptococcus macedonicus (formally S. gallolyticus subsp macedonicus) (7.1\%), Pediococcus pentosaceus (5.4\%) and Enterococcus faecalis $(5.4 \%)$.

L. casei Group comprised most of the isolates with anti-clostridial activity ( 37 out of 56). The high degree of phenotypic similarity and phylogenetic proximity between species makes it difficult to discriminate between them, both by biochemical tests as well as by molecular biology techniques, such as 16S rRNA gene sequencing (Iacumin et al., 2015; Huang et al., 2018). Due to this, $12.5 \%$ (7 out of 56) were identified as L. casei, while 7.1\% (4 out of 56) and 26.8\% (15 out of 56) corresponded to $L$. paracasei and $L$ rhamnosus, respectively. Unidentified isolates were named as $L$. casei Group strains.

Anti-clostridial activity of LAB isolates and commercial strain L. casei BAL C was evaluated by disc diffusion method, sixteen isolates with the highest anticlostridial activity were selected (Fig. $1 \mathrm{~A}$ ). The diameters of the inhibition halos generated by these isolates were compared with L. casei BAL C (Fig. 1 B). Four $\mathrm{LAB}$ isolates that presented lower inhibitory activity $(\mathrm{p}<0.05)$ than $L$. casei $\mathrm{BAL}$ $\mathrm{C}$ were discarded from further analysis. Seven isolates with the highest anticlostridial activity were selected. Table 1 shows the source and 16S rRNA sequence identity of the selected anti-clostridial LAB isolates, as well as their classification into SLAB and NSLAB strains according to literature criteria (Reginensi et al., 2016; Blaya et al., 2018). Except for strain 76, all isolates were classified as NSLAB classified strains. The NSLAB population develops in the cheese ripening stage and becomes the predominant microflora. As at this stage, Clostridium also proliferates and causes late blowing defect, several researchers believe that NSLAB strains compatible with the cheese making process would be more suitable for inhibiting Clostridium spp. and prevent the appearance of the defect (Ristagno, 2013; Bowen, 2018; Şatana, 2018). 


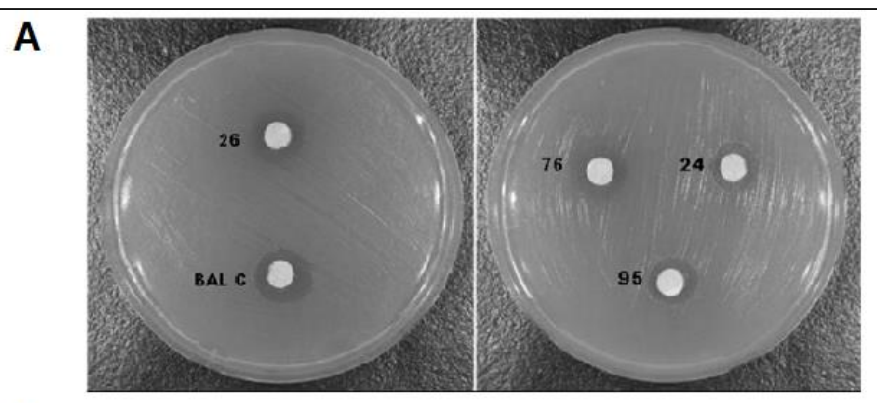

B

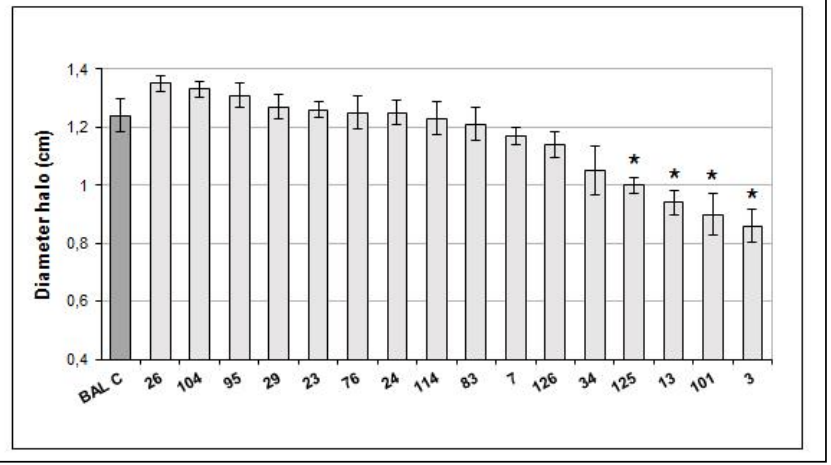

Figure 1 (A) Evaluation of inhibitory activity of anti-clostridial LAB isolates by disc diffusion method against to $C$. tyrobutyricum ATCC25755. (B) Comparison of diameter $(\mathrm{cm})$ of inhibition halos produced by LAB isolates (gray bars) and $L$. casei BAL C (dark gray bar). Asterisks indicate strains with significantly lower inhibitory activity than BAL C ( $\mathrm{p}<0.05)$.

Table 1 SLAB and NSLAB isolates selected by agar disc diffusion method.

$\begin{array}{cccc}\text { Strain } & \text { Identification } & \text { Source } & \text { LAB type } \\ 29 & \text { L. casei Group } & \text { cheese } & \text { NSLAB } \\ 26 & \text { L. casei } & \text { cheese } & \text { NSLAB } \\ 95 & \text { L. casei } & \text { raw milk } & \text { NSLAB } \\ 23 & \text { S. macedonicus } & \text { cheese } & \text { NSLAB } \\ 24 & \text { S. macedonicus } & \text { cheese } & \text { NSLAB } \\ 104 & \text { L. rhamnosus } & \text { raw milk } & \text { NSLAB } \\ 76 & \text { L. delbrueckii subsp. } & \text { raw milk } & \text { SLAB } \\ & \text { bulgaricus } & & \end{array}$

\section{Nature of anti-clostridial compounds and sensitivity to heat treatments}

Anti-clostridial mechanisms of the selected LAB strains and L. casei BAL C were elucidated in neutralized cell free supernatants obtained from the strain cultured in MRS broth. S. macedonicus 23, S. macedonicus 24, Lactobacillus sp. 29 and L. rhamnosus 104 supernatants lost anti-clostridial activity after neutralization, hence inhibitory activity was due to organic acids production. Organic acids are products of lactic acid fermentation with antibacterial activity which effectiveness depends on the chemical structure, the amount produced, and the food matrix pH (Gutierres, 2018; Bushell et al., 2019). Clostridium species responsible for late blowing defect are inhibited at $\mathrm{pH} 4$, but hard and semi-hard cheeses have a $\mathrm{pH}$ range of 5.2 - 5.5. Therefore, LAB strains whose anticlostridial activity is due solely to the organic acids production may not be effective to inhibit Clostridium spp. in cheese matrix (Drouin and Lafrenière, 2012; D'Incecco et al., 2018; Nuñez et al., 2020).

Supernatants of strains L. casei 26, L. casei Group 29, L. delbrueckii subsp. bulgaricus 76 and $L$. casei BAL C retained the inhibitory effect after neutralization. Therefore, supernatants were treated with catalase and proteinase $\mathrm{K}$ to determine whether inhibitory activity corresponded to $\mathrm{H}_{2} \mathrm{O}_{2}$ or bacteriocin production. For all treatments, residual anti-clostridial activity was expressed as a percentage of inhibitory activity produced by neutralized supernatants (Tab. 2). Hydrogen peroxide was produced by $L$. delbrueckii subsp. bulgaricus 76 and responsible for the anti-clostridial activity, as catalase treatment lead to a residual anti-clostridial activity of $5.7 \%$. Peptidic anti-clostridial compounds were not detected for this strain. Hydrogen peroxide generation of by L. delbrueckii subsp. bulgaricus strains has been frequently reported (Adesokan et al., 2010; Hertzberger et al., 2014; Selle $\boldsymbol{e t}$ al., 2019). Hydrogen peroxide is an effective bacteriostatic or bactericide agent that acts by oxidizing cellular components such as cell membrane lipids, proteins and DNA. In addition, this compound has a sporicidal effect on Clostridium and Bacillus spores. Cytotoxic effect of hydrogen peroxide depends on factors such as its concentration, aeration, bacterial sensitivity to oxidation stress, $\mathrm{pH}$ and temperature conditions (Brudzynski et al., 2011; Queiroux et al., 2018; Uwamahoro et al., 2018;

Vieco-Saiz et al., 2019). It is important to note that an essential factor for the hydrogen peroxide production by LAB strains is the presence of $\mathrm{O}_{2}$, so it is valid to question whether this strategy would be effective in cheese matrix where oxygen diffusion is low (Brudzynski et al., 2011; Levante, 2017; Lavazani, 2018; Hernandez et al., 2019).

Table 2 Residual anti-clostridial activity (\%) of neutralized cell-free supernatants*

\begin{tabular}{ccccc}
\hline $\begin{array}{c}\text { SN } \\
\text { treatment }\end{array}$ & $\begin{array}{c}\text { L. casei } \\
\text { BAL C }\end{array}$ & L. casei 26 & L. casei 95 & $\begin{array}{c}\text { L. delbrueckii } \\
\text { subsp. } \\
\text { bulgaricus 76 }\end{array}$ \\
\hline Proteinase K & $12,4 \%$ & $65,2 \%$ & $80,5 \%$ & $98,1 \%$ \\
Catalase & $71,2 \%$ & $39,3 \%$ & $28,3 \%$ & $5,7 \%$ \\
HT $_{1}$ & $97,4 \%$ & $73,0 \%$ & $97,3 \%$ & $98,5 \%$ \\
HT $_{2}$ & $73,7 \%$ & $58,4 \%$ & $93,8 \%$ & $90,6 \%$ \\
\hline
\end{tabular}

HT1: Heat treatment at $70{ }^{\circ} \mathrm{C}$ during $15 \mathrm{~min}$

HT2: Heat treatment at $100{ }^{\circ} \mathrm{C}$ for $15 \mathrm{~min}$.

* Residual anti-clostridial activity was calculated as a percentage of neutralized supernatants without enzymatic or thermal treatment inhibitory activity

Residual inhibitory activity of $L$. casei 26 and 95 supernatants treated with catalase was $39.3 \%$ and $28.3 \%$, respectively, while proteinase $\mathrm{K}$ treatment preserved $65.2 \%$ and $80.5 \%$ of the antimicrobial activity (Tab. 2). According to these data, anti-clostridial activity of $L$. casei 26 and 95 is due to the production of hydrogen peroxide and proteinaceous compounds. It is worth mentioning that the production of bacteriocins and hydrogen peroxide are characteristics frequently reported in the genus Lactobacillus (Davoodabadi et al., 2015; Collins et al., 2017; Queiroux et al., 2018; Li et al., 2019). According to the results obtained, commercial bioprotective $L$. casei $\mathrm{BAL} \mathrm{C}$ is a bacteriocinogenic strain, but remaining anti-clostridial activity in catalase treated supernatant $(71.2 \%)$, indicated that hydrogen peroxide was also present.

Thermal stability of neutralized cell-free supernatants was tested at 70 and $100{ }^{\circ} \mathrm{C}$ (Tab. 2). All supernatants conserved their inhibitory activity after the heat treatments performed. L. casei 26 supernatant was susceptible to thermal treatments reducing half of its anti-clostridial activity at $100{ }^{\circ} \mathrm{C}(58.4 \%)$ Supernatants of $L$. casei BAL C and 95 presented higher thermal resistance, retaining a suitable inhibitory activity even after $100{ }^{\circ} \mathrm{C}$ treatment. L. delbrueckii subsp. bulgaricus 76 supernatant retained most of its anti-clostridial activity after the heat treatments performed.

In this work, the nature of anti-clostridial compounds was elucidated focusing on the search for organic acids, hydrogen peroxide and peptide compounds. Table 3 summarizes the anti-clostridial mechanisms detected in the evaluated LAB strains and the isolation sources from which they were obtained. The presence of other anti-clostridial compounds such as D-amino acids, acetaldehyde, diacetyl or acetoin in the supernatants can not be dismissed.

Table 3 Nature of anti-clostridial compounds produced by LAB strains.

\begin{tabular}{ccc}
\hline Strain & Isolation source & Inhibition mechanism \\
\hline L. casei BAL C & commercial strain & $\begin{array}{c}\text { organic acids, hydrogen } \\
\text { peroxide, bacteriocin }\end{array}$ \\
S. macedonicus 23 & cheese & organic acids \\
S. macedonicus 24 & cheese & organic acids
\end{tabular}

L. casei $26 \quad$ cheese

organic acids, hydrogen peroxide, bacteriocin

L. casei $95 \quad$ raw milk organic acids, hydrogen peroxide, bacteriocin

L. casei/paracasei $29 \quad$ cheese organic acids

L. rhamnosus $104 \quad$ raw milk organic acids

L. delbrueckii subsp. raw milk organic acids, hydrogen bulgaricus 76 peroxide

\section{Purification and characterization of anti-clostridial peptides}

The anti-clostridial peptides present in cell-free supernatants of bacteriocinogenic strains L. casei BAL C, 26 and 95 were purified by RP-HPLC. For each supernatant different fractions could be clearly resolved under the conditions employed. Four peaks showing an absorption at $220 \mathrm{~nm}$ were individually collected from $L$. casei 26 and 95 supernatants. Only one fraction corresponding 
to retention time of 14 - 16 min. was collected from $L$. casei BAL C supernatant. All fractions were tested for anti-clostridial activity by disc diffusion assay (Tab 4). Fractions $\mathrm{P}_{2}$ and $\mathrm{P}_{4}$ of L. casei 26, $\mathrm{P}_{1}$ and $\mathrm{P}_{4}$ of L. casei 95 and $\mathrm{P}_{0}$ of L. case BAL C were found to have activity against $C$. tyrobutyricum ATCC 25755.

All fractions with anti-clostridial activity were subjected to mass spectrometry analysis for compounds identification. MALDI-TOF analysis only resulted in suitable mass spectrum for $\mathrm{P}_{0}$ fraction of $L$. casei BAL C and $\mathrm{P}_{4}$ of $L$. casei 95 (Fig. 2). The low resolution of mass spectra obtained could be due to background noise produced by ions originated from compounds presents in HPLC fractions. One source of background noise are culture medium components. LAB have harsh nutritional requirements so they require complex culture media, allowing better bacterial growth and increased bacteriocin production. The disadvantage of this type of culture media is the high presence of proteins and other culture medium compounds that are difficult to eliminate in the purification process Others undesired contaminants could be bacterial metabolic products, degradation of liquid chromatographic column and leachables of recipients (De Vijlder et al., 2018; Sidek et al., 2018).
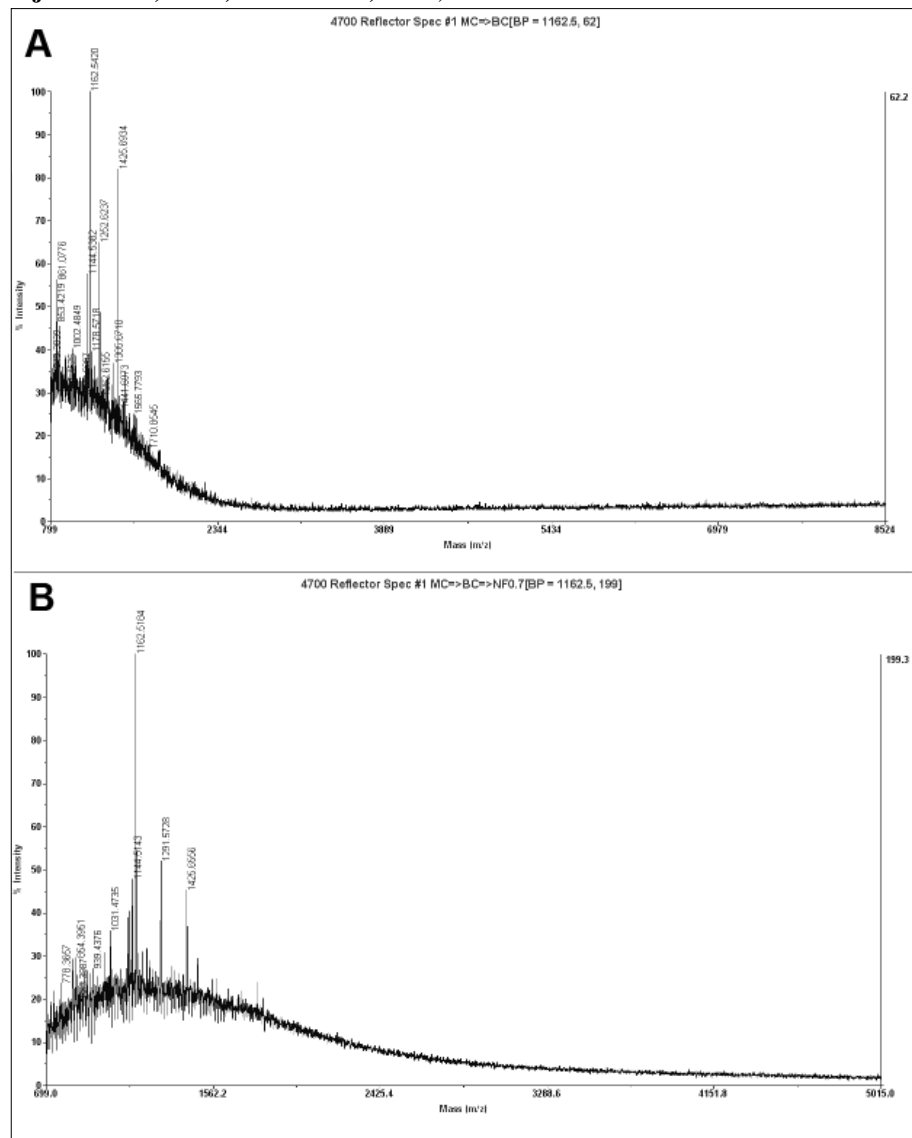

Figure 2 MALDI-TOF mass spectra of $L$. casei BAL C $\mathrm{P}_{0}$ fraction (A) and $L$. casei $95 \mathrm{P}_{4}$ fraction (B).

The obtained molecular mass of the L. casei BAL C $\mathrm{P}_{0}$ fraction was 1162.54 (retention time: 14 - 14 min.), while for $L$. case $i 95 \mathrm{P}_{4}$ fraction it was $1162.52 \mathrm{Da}$ (retention time: 22 - 26 min.). The low intensity of the mass spectrum signals did not allow to obtain fragmentation spectra (MS/MS) from the resulting peptide ions and therefore structural information of the compound was not found. No results were obtained for MALDI-TOF analysis of $L$. casei $95 \mathrm{P}_{4}$ fraction and $L$. casei $26 \mathrm{P}_{2}$ and $\mathrm{P}_{4}$ fractions. This may be due to the degradation of anti-clostridial peptides presents in the supernatants by proteases from bacteriocinogenic strains or the low concentration of the bacteriocins produced. The production of bacteriocins depends on several parameters such as the composition and $\mathrm{pH}$ of the culture medium, temperature and the growth kinetics of the producing microorganism. In many cases the maximum production of bacteriocin occurs under conditions other than optimal for bacterial growth (Spivak, 2010; Saavedra and Sesma, 2011; Relloso et al., 2015; Sidooski et al., 2019). In spite of not having obtained structural information about the anti-clostridial compound present in $\mathrm{P}_{0}$ L. casei $\mathrm{BAL} \mathrm{C}$ and $\mathrm{P}_{4}$ L. casei 95 fractions, thermotolerance and low molecular weight $(<10 \mathrm{kDa})$ of both compounds would imply that they are class I or II bacteriocins (da Costa et al., 2019; Hols et al., 2019).

\section{CONCLUSION}

From raw milk, artisan cheese and whey samples analyzed in this work, 56 LAB strains with inhibitory activity against $C$. tyrobutyricum ATCC 25755 were isolated. Seven of these isolates had anti-clostridial activity similar to the commercial-strain L. casei BAL C and their inhibition mechanisms were studied Inhibitory action of four isolates tested $(23,24,29$ and 104) were due only to acid production, whereas antimicrobial activity of isolates 26, 76 and 95 was due to the production of other antimicrobial metabolites besides organic acid production. In the case of L. casei strains 26 and 95, organic acid, hydrogen peroxide and bacteriocins production was observed, while the inhibition developed by $L$. delbrueckii subsp. bulgaricus 76 was due to its acidifying activity and hydrogen peroxide generation. L. casei strains 26, 95 and BAL C anti-clostridial peptides were thermo-resistant. Mass spectrometry analysis MALDI-TOF allowed to detect inhibitory peptide compounds produced by $L$. casei strains 95 and BAL C with a molecular weight of $1.2 \mathrm{kDa}$. Due to the thermostability and low molecular weight of these compounds, they would be bacteriocins of the classes I or II. The characterization of bacteriocins produced by L. casei 26 and L. casei 95 is an issue that should be addressed in the future.

Acknowledgments: Authors thank MSc. Jorge Bermúdez for proposing this line of research and his contributions throughout the development of the project. This research was carried out with funding from CSIC Initiation (Project ID number: 406).

Table 4 Retention time and anti-clostridial activity of HPLC fractions.

\begin{tabular}{|c|c|c|c|c|c|c|c|c|c|}
\hline \multirow[b]{2}{*}{ HPLC fraction } & \multicolumn{4}{|c|}{ L. casei 26} & \multicolumn{4}{|c|}{ L. casei 95} & \multirow{2}{*}{$\frac{\text { L. casei BAL C }}{\mathrm{P}_{0}}$} \\
\hline & $\mathrm{P}_{1}$ & $\mathrm{P}_{2}$ & $\mathrm{P}_{3}$ & $\mathrm{P}_{4}$ & $\mathrm{P}_{1}$ & $\mathrm{P}_{2}$ & $\mathrm{P}_{3}$ & $\mathrm{P}_{4}$ & \\
\hline retention time (min.) & $3-6$ & $7-9$ & $10-14$ & $14-21$ & $3-4$ & $4-6$ & $14-20$ & $22-26$ & $14-16$ \\
\hline $\begin{array}{c}\text { anti-clostridial } \\
\text { activity }\end{array}$ & - & + & - & + & + & - & - & + & + \\
\hline
\end{tabular}

(+/-): presence/absence of inhibition halo in disc diffusion assay

\section{REFERENCES}

ADESOKAN, I.A., EKANOLA, Y.A., OKANLAWON, B.M. 2010. Influence of cultural conditions on hydrogen peroxide production by lactic acid bacteria isolated from some Nigerian traditional fermented foods. African Journal of Microbiology Research, Vol. 4, No. 9, 1991 - 1996.

ALVENÄS, A. 2015. Cheeses with blowing defects. Problematics and preventable methods. Independent Project in Food Science. Bachelor thesis. Swedish University of Agricultural Sciences, Publikation/Sveriges lantbruksuniversitet, Institutionen för livsmedelsvetenskap, No. 412. Uppsala, Sweden.

ÁVILA, M., GÓMEZ-TORRES, N., HERNÁNDEZ, M., GARDE, S. 2014 Inhibitory activity of reuterin, nisin, lysozyme and nitrate against vegetative cells and spores of dairy-related Clostridium species. International Journal of Food Microbiology, 172, 70 - 75. https://doi.org/10.1016/j.ijfoodmicro.2013.12.002 BERMÚDEZ, J., GONZÁLEZ, M.J., OLIVERA, J.A., BURGUEÑO, J.A., JULIANO, P., FOX, E.M., REGINENSI, S.M. 2016. Seasonal ocurrence and molecular diversity of clostridia species spores along cheesemaking streams of 5 commercial dairy plants. Journal of Dairy Science, 99, 1 - 9. https://doi.org/10.3168/jds.2015-10079

BLAYA, J., BARZIDEH, Z., LAPOINTE, G. 2018. Symposium review: interaction of starter cultures and nonstarter lactic acid bacteria in the cheese environment. Journal of Dairy Science, Vol. 101, No. 4, 3611 - 3629. https://doi.org/10.3168/jds.2017-13345

BOWEN, B.I. 2018. Growth characteristics of Lactobacillus wasatchensis and its detection and enumeration using quantitative polymerase chain reaction. Master thesis. Utah State University. Logan, Utah. All Graduate Theses and Dissertations, 7273

BRÄNDLE, J., DOMIG, K.J., KNEIFEL, W. 2016. Relevance and analysis of butyric acid producing clostridia in milk and cheese. Food Control, 67, 96 - 113 https://doi.org/10.1016/j.foodcont.2016.02.038

BRUDZYNSKI, K., ABUBAKER, K., ST.-MARTIN, L., CASTLE, A. 2011 Re-examining the role of hydrogen peroxide in bacteriostatic and bactericidal 
activities of honey. Frontiers in Microbiology, Vol. 2, Art. 213 https://doi.org/10.3389/fmicb.2011.00213

BUSHELL, F.M.L., TONNER, P.D., JABBARI, S., SCHMID, A.K., LUND, P.A. 2019. Synergistic impacts of organic acids and $\mathrm{pH}$ on growth of Pseudomonas aeruginosa: a comparison of Parametric and Bayesian nonparametric methods to model growth. Frontiers in Microbiology, 9: 3196 https://doi.org/10.3389/fmicb.2018.03196

CALAMARI, L., MORERA, P., BANI, P., MINUTI, A., BASIRICÒ, L., VITALI, A., BERNABUCCI, U. 2018. Effect of hot season on blood parameters, fecal fermentative parameters, and occurrence of Clostridium tyrobutyricum spores in feces of lactating dairy cows. Journal of Dairy Science, Vol. 101, No. 5, 4437 - 4447. https://doi.org/10.3168/jds.2017-13693

CHRISTIANSEN, P., PETERSEN, M.H., KASK, S., MØLLER, P.L., PETERSEN, M., NIELSEN, E.W., VOGENSEN, F.K., ARDÖ, Y. 2005. Anticlostridial activity of Lactobacillus isolated from semi-hard cheeses. $\begin{array}{lllll}\text { International Dairy Journal, } & 15, & 901 & - & 909\end{array}$ https://doi.org/10.1016/j.idairyj.2004.07.022

COLLINS, F.W.J., O'CONNOR, P.M., O'SULLIVAN, O., GÓMEZ-SALA, B. REA, M.C., HILL, C., ROSS, R.P. 2017. Bacteriocin gene-trait matching across the complete Lactobacillus pan-genome. Scientific Reports, Vol. 7, No. 1, 3481. https://doi.org/10.1038/s41598-017-03339-y

DA COSTA, R.J., VOLOSKI, F.L.S, MONDADORI, R.G., DUVAL, E.H. FIORENTINI, Â.M. 2019. Preservation of meat products with bacteriocins produced by lactic acid bacteria isolated from meat. Journal of Food Quality, Vol. 2019, Art. ID 4726510, 1 - 12 https://doi.org/10.1155/2019/4726510DAVOODABADI, A., SOLTANDALLAL, M.M., LASHANI, E., TAJABADI-EBRAHIMI, M. 2015 Antimicrobial activity of Lactobacillus spp. isolated from fecal flora of healthy breast-fed infants against diarrheagenic Escherichia coli. Jundishapur Journal of Microbiology, 8 (12): e27852. https://doi.org/10.5812/jim.27852

DE VIJLDER, T., VALKENBORG, D., LEMIËRE, F., ROMIJN, E.P., LAUKENS, K., CUYCKENS, F. 2018. A tutorial in small molecule identification via electrospray ionization-mass spectrometry: the practical art of structural elucidation. Mass Spectrometry Reviews, Vol. 37, No. 5, 607 - 629 https://doi.org/10.1002/mas.21551DICKMAN, R., MITCHELL, S.A., FIGUEIREDO, A.M., HANSEN, D.F., TABOR, A.B. 2019. Molecular recognition of lipid II by lantibiotics: synthesis and conformational studies of analogues of nisin and mutacin rings A and B. The Journal of Organic Chemistry, Vol. 84, No. 18, $11493 \quad$ - 11512 https://doi.org/10.1021/acs.joc.9b01253

D'INCECCO, P., PELLEGRINO, L., HOGENBOOM, J.A., COCCONCELLI, P.S., BASSI, D. 2018. The late blowing defect of hard cheese: behaviour of cells and spores of Clostridium tyrobutyricum throughout the cheese manufacturing and ripening. $L W T$, Vol. 87, 134 - 141. https://doi.org/10.1016/j.lwt.2017.08.083 DROUIN, P., LAFRENIERE, C. 2012. Clostridial spores in animal feeds and milk. In: Chaiyabutr, N. (Ed.), Milk-production - An up-to-date overview of animal nutrition, management and health. Chapter 18, 375 - 394. InTech. https://doi.org/10.5772/50775

GARCÍA-CANO, I., ROCHA-MENDOZA, D., ORTEGA-ANAYA, J., WANG, K., KOSMERL, E., JIMÉNEZ-FLORES, R. 2019. Lactic acid bacteria isolated from dairy products as potential producers of lipolytic, proteolytic and antibacterial proteins. Applied Microbiology and Biotechnology, Vol. 103, No. 13 , 5243 - 5257. https://doi.org/10.1007/s00253-019-09844-6

GARDE, S., ARIAS, R., GAYA, P., NUÑEZ, P. 2011. Occurrence of Clostridium spp. in ovine milk and Manchego cheese with late blowing defect identification and characterization of isolates. International Dairy Journal, 21 272 - 278. https://doi.org/10.1016/j.idairyj.2010.11.003

GARDE, S., ÁVILA, M., ARIAS, R., NÚÑEZ, M. 2013. Sugars and organic acids in raw and pasteurized milk Manchego cheeses with different degrees of late blowing defect. International Dairy Journal, 25, 87-91. https://doi.org/10.1016/j.idairyj.2012.01.005

GOMEZ, T.N. 2017. Control of Clostridium spp. and prevention of late blowing defect of cheese by antimicrobial-producing lactic acid bacteria, high pressure and phage endolysins. Doctoral thesis. Universidad Complutense de Madrid. Madrid, España.

GUPTA, T.B., BRIGHTWELL, G. 2017. Farm level survey of spore-forming bacteria on four dairy farms in the Waikato region of New Zealand. Wiley Micrbiology Open, e457. https://doi.org/10.1002/mbo3.457

GUTIERRES, M.D.L. 2018. Efecto de los ácidos acético y cítrico para el control de antracnosis (Colletotrichum sp.) en poscosecha de papaya (Carica papaya $\mathrm{L}$.) Tesis de Grado. Universidad Central de Ecuador. Quito, Ecuador.

HERNANDEZ, P., SAGER, B., FA, A., LOZANO, C., KHAZZAM, M. 2019 Bactericidal efficacy of hydrogen peroxide on Cutibacterium acnes. Bone \& Joint Research, Vol. 8, No. 1, 3 - 10. https://doi.org/10.1302/2046-3758.81.bjr2018-0145.r1

HERTZBERGER, R., ARENTS, J., DEKKER, H.L., PRIDMORE, R.D., GYSLER, C., KLEEREBEZEM, M., TEXEIRA, DE M.M.J. 2014. $\mathrm{H}_{2} \mathrm{O}_{2}$ production in species of the Lactobacillus acidophilus Group: a central role for a novel NADH-dependent flavin reductase. Applied and Environmental
Microbiology, Vol. 80, No. 7, 2229 - 2239. https://doi.org/10.1128/AEM.0427213

HOLS, P., LEDESMA-GARCÍA, L., GABANT, P., MIGNOLET, J. 2019. Mobilization of microbiota commensals and their bacteriocins for therapeutics Trends in Microbiology, Vol. 27, No. $8,690 \quad-\quad 702$ https://doi.org/10.1016/j.tim.2019.03.007IACUMIN, L., GINALDI, F. MANZANO, M., ANASTASI, V., REALE, A., ZOTTA, T., ROSSI, F., COPPOLA, R., COMI, G. 2015. High resolution melting analysis (HRM) as a new tool for the identification of species belonging to the Lactobacillus case group and comparison with species-specific PCRs and multiplex PCR. Food Microbiology, 46, 357 - 367. https://doi.org/10.1016/j.fm.2014.08.007

JONES, R.J., HUSSEIN, H.M., ZAGOREC, M., BRIGHTWELL, G., TAGG, J.R. 2008. Isolation of lactic acid bacteria with inhibitory activity against pathogens and spoilage organisms associated with fresh meat. Food Microbiology, 25, 228 - 234. https://doi.org/10.1016/j.fm.2007.11.001

KOMORI, K., OHKUBO, Y., KATANO, N., MOTOSHIMA, H. 2018. One year investigation of the prevalence and diversity of clostridial spores in raw milk from the Tokachi area of Hokkaido. Japanese Society of Animal Science, Vol. 90 135 - 139. https://doi.org/10.1111/asj.13135

KUMARIYA, R., GARSA, A.K., RAJPUT, Y.S., SOOD, S.K., AKHTAR, N. PATEL, S. 2019. Bacteriocins: classification, synthesis, mechanism of action and resistance development in food spoilage causing bacteria. Microbial Pathogenesis, Vol. 128, 171 - 178.https://doi.org/10.1016/j.micpath.2019.01.002 LAVAZANI, A.S. 2018. Biochemical changes of Iranian probiotic Lighvan cheese. Czech Journal of Food Sciences, Vol. 36, No. 2, 181 - 186 https://doi.org/10.17221/453/2016-cjfs

LEVANTE, A. 2017. New findings on the adaptation of Lactobacillus casei group to cheese environment. Doctoral thesis. Universita' degli Studi di Parma. Parma, Italy.

LI, T., LIU, Z., ZHANG, X., CHEN, X., WANG, S. 2019. Local probiotic Lactobacillus crispatus and Lactobacillus delbrueckii exhibit strong antifungal effects against vulvovaginal candidiasis in a rat model. Frontiers in Microbiology, 10: 1033.https://doi.org/10.3389/fmicb.2019.01033

LÜ, X., HU, P., DANG, Y., LIU, B. 2014. Purification and partial characterization of a novel bacteriocin produced by Lactobacillus casei $\mathrm{TN}-2$ isolated from fermented camel milk (Shubat) of Xinjiang Uygur Autonomous region, China. Food Control, 43, 276 - 283. http://doi.org/10.1016/j.foodcont.2014.03.020

MARTÍNEZ, B., RODRÍGUEZ, A., SUÁREZ, E. 2016. Antimicrobial peptides produced by bacteria: the bacteriocins. In: Villa, T.G. and Vinas, M. (Eds.), New weapons to control bacterial growth, pp. 15 - 38. Springer International Publishing Switzerland. https://doi.org/10.1007/978-3-319-28368-5_2

MATAMOROS, S., PILET, M.F., GIGOUT, F., PRÉVOST, H., LEROI, F. 2009. Selection and evaluation of seafood-borne psychrotropic lactic acid bacteria as inhibitors of pathogenic and spoilage bacteria. Food Microbiology, 26, 638 - 644 https://doi.org/10.1016/j.fm.2009.04.011

MATHOT, A.G., BELIARD, E., THUAULT, D. 2003. Streptococcus thermophilus 580 produces a bacteriocin potentially suitable for inhibition of Clostridium tyrobutyricum in hard cheese. Journal of Dairy Science, 86, 3068 3074. https://doi.org/10.3168/jds.S0022-0302(03)73906-X

NUÑEZ, M., CALZADA, J., DEL OLMO, A. 2020. High pressure processing of cheese: lights, shadows and prospects. International Dairy Journal, Vol. 100, 104558 - 104580. https://doi.org/10.1016/j.idairyj.2019.104558

ÖZUGUL, F., HAMED, I. 2018. The importance of lactic acid bacteria for the prevention of bacterial growth and their biogenic amines formation: a review. Critical Reviews in Food Science and Nutrition, Vol. 58, No. 10, 1660 - 1670. https://doi.org/10.1080/10408398.2016.1277972

PAL, V., PAL, A., PATIL, M., RAMANA, K.V., JEEVARATNAM, K. 2010. Isolation, biochemical properties and application of bacteriocins from Pediococcus pentosaceus isolates. Journal of Food Processing and Preservation, 34, 1064 - 1079. https://doi.org/10.1111/j.1745-4549.2009.00438.x

PEREZ, R.H., ZENDO, T., SONOMOTO, K. 2014. Novel bacteriocins from lactic acid bacteria (LAB): various structures and applications. Microbial Cell Factories, Vol. 13, Suppl. 1, S3. https://doi.org/10.1186/1475-2859-13-s1-s3 QUEIROUX, C., BONNET, M., SARAOUI, T., DELPECH, P., VEISSEIRE, P., RIFA, E., MOUSSARD, C., GAGNE, G., DELBÈS, C., BORNES, S. 2018 Dialogue between Staphylococcus aureus SA15 and Lactococcus garvieae strains experiencing oxidative stress. BMC Microbiology, Vol. 18, No. 1. https://doi.org/10.1186/s12866-018-1340-3

REGINENSI, S.M., OLIVERA, J.A., BERMÚDEZ, J., GONZÁLEZ, M.J.. 2016. Lactobacillus in the dairy industry: from natural diversity to biopreservative resources. In: Castro-Sowinski (Ed.), Microbial models: from environmental to industrial sustainability, Microorganisms for sustainability. Vol. 1, Chapter 4, 57 - 81. Springer Science+Business Media Singapore. https://doi.org/10.1007/978981-10-2555-6 4

RELLOSO, M.S., NIEVAS, J., FARES, T.S., FARQUHASON, V., MUJICA, M.T., ROMANO, V., ZARATE, M.S., SMAYEVSKY, J.. 2015. Evaluación de la espectrometría de masas: MALDI-TOF MS para la identificación rápida y confiable de levaduras. Revista Argentina de Microbiología, 47 (2): 103 - 107 https://doi.org/10.1016/j.ram.2015.02.004 
RISTAGNO, D. 2013. Evaluation of microbial adjuntcs and their effect on the ripening of Cheddar cheese. Doctoral thesis. University College Cork. Cork, Ireland.

SAAVEDRA, L., SESMA, F. 2011. Purification techniques of bacteriocins from lactic acid bacteria and other Gram-positive bacteria. In: Drider, D. and Rebuffat, S. (Eds.), Prokaryotic antimicrobial peptides: from genes to applications. Chapter 7, 99 - 113. Springer Science+Business Media. https://doi.org/10.1007/978-14419-7692-5_7

ŞATANA, E. 2018. Preparation, production and industrial application of cheese protective cultures. Doctoral thesis. Izmir Institute of Technology. Izmir, Turkey. SATO, H., TORIMURA, M., KITAHARA, M., OHKUMA, M., HOTTA, Y., TAMURA, H. 2012. Characterization of Lactobacillus casei group based on the profiling of ribosomal proteins coded in S10-spc-alpha operons as observed by MALDI-TOF MS. Systematic and Applied Microbiology, 35, 447 - 454 https://doi.org/10.1016/j.syapm.2012.08.008

SELLE, K., ANDERSEN, J.M., BARRANGOU, R. 2019. Short communication: Transcriptional response to a large genomic island deletion in the dairy starter culture Streptococcus thermophilus. Journal of Dairy Science, Vol. 102, No. 9 7800 - 7806. https://doi.org/10.3168/jds.2019-16397

SIDEK, N.L.M., HALIM, M., TAN J.S., ABBASILIASIM, S., MUSTAFA, S ARIFF, A.B. 2018. Stability of bacteriocin-like inhibitory substance (BLIS) produced by Pediococcus acidilatici $\mathrm{kp10}$ at different extreme conditions BioMed Research International, Vol. 2018, Art. ID 5973484, 1 - 11. https://doi.org/10.1155/2018/5973484SIDOOSKI, T., BRANDELLI, A., BERTOLI, S.L., DE SOUZA, K.C., DE CARVALHO, F.L. 2019. Physical and nutritional conditions for optimized production of bacteriocins by lactic acid bacteria - A review. Critical Reviews in Food Science and Nutrition, Vol. 59, No. 17, 2839 - 2849. https://doi.org/10.1080/10408398.2018.1474852

SILVA, C.C.G., SILVA, S.P.M, RIBEIRO, S.C. 2018. Application of bacteriocins and protective cultures in dairy food preservation. Frontiers in Microbiology, 9: 594. https://doi.org/10.3389/fmicb.2018.00594

SPIVAK, M. 2010. Analysis of mass spectrometry data for protein identification in complex biological mixtures. Doctoral thesis. New York University. New York, United States.

UWAMAHORO, M.C., MASSICOTTE, R., HURTUBISE, Y., GAGNÉBOURQUE, F., MAFU, A.A., YAHIA, L. 2018. Evaluating the sporicidal activity of disinfectants against Clostridium difficile and Bacillus amyloliquefaciens spores by using the improved methods based on ASTM E2197-11. Frontiers in Public Health, Vol. 6, No. 18 https://doi.org/10.3389/fpubh.2018.00018

VIECO-SAIZ, N., BELGUESMIA, Y., RASPOET, R., AUCLAIR, E., GANCEL, F., KEMPF, I., DRIDER, D. 2019. Benefits and inputs from lactic acid bacteria and their bacteriocins as alternatives to antibiotic growth promoters during food-animal production. Frontiers in Microbiology, Vol. 10, No. 57 https://doi.org/10.3389/fmicb.2019.00057

WEISBURG, W.G., BARNS, S.M., PELLETIER, D.A., LANE, D.J. 1991. 16S ribosomal DNA amplification for phylogenetic study. Journal of Bacteriology, 173, 697-703. https://doi.org/10.1128/jb.173.2.697-703.1991

YANG, Z. 2000. Antimicrobial compounds and extracellular polysaccharides produced by lactic acid bacteria: structures and properties. Academic dissertation. University of Helsinki. Helsinki, Finland.

ZALÁN, Z., NÉMETH, E., BARÁTH, Á., HÁLASZ, A. 2005. Influence of growth medium on hydrogen peroxide and bacteriocin production of Lactobacillus strains. Food Technology and Biotechonology, Vol. 43, No. 3, 219 $-225$. 